\title{
Semantīk
}

Volume 6, No. 2, September 2017

\section{PERANAN SOFT SKILL DAN MINAT BACA TERHADAP KEMAMPUAN MENULIS EKSPOSISI MATA PELAJARAN BAHASA INDONESIA}

\author{
Sigit Widiyarto \\ Universitas Indraprasta PGRI Jakarta \\ widiyartosigit@gmail.com
}

\begin{abstract}
Abstrak
Penelitian ini menjelaskan peranan Soft Skill dan Minat baca terhadap kemampuan Menulis Eksposisi pada Mata Pelajaran Bahasa Indonesia.Subyek penelitian adalah siswa kelas XI Adan XI B SMA AlIkhlas Kota Bekasi, sebanyak 44 siswa. Metode penelitian ini memakai analisis statistik deskriptif. Pengolahan data dengan memakai SPSS 22. Teknik pengambilan data memakai Sampel Random Sampling. Pengumpulan data melalui wawancara, angket dan Tes. Soft Skill dapat mempengaruhi kemampuan Menulis. Kemampuan menulis Eksposisi tergambar siswa yang mempunyai soft skill katagori baik sebesar 45.5\%.19 siswa katagori cukup (43.1\%) dan siswa katagori kurang sebanyak 5 siswa $(11.4 \%)$. Siswa yang mempunyai minat baca katagori baik sebanyak 11 siswa (25\%), 4 siswa katagori cukup $(9.1 \%)$ dan 29 siswa kategori kurang $(65,9 \%)$. Pada kemampuan menulis siswa yang mempunyai kemampuan menulis katagori baik sebanyak 18 siswa (41\%), cukup sebanyak 13 siswa $(29.5 \%)$ dan kurang sebanyak 13 siswa $(29,5 \%)$.
\end{abstract}

\section{Pendahuluan}

Peran model pembelajaran yang digunakan oleh para guru menentukan keberhasilan belajar siswa. Kecakapan yang diperlukan tidak hanya kecakapan akademik, kecakapan soft skill juga diperlukan. Pembelajaran yang menekankan pada peningkatan soft skill akan membantu kesiapan siswa dalam menghadapi era globalisasi. Baik dilihat dari segi kognitif dan afektif karena pembelajaran yang baik adalahyang dapat menyesuaikan antara tujuan yang menyeluruh (Holistik) dan proses belajar mengajar. Hard Skill meliputi nilai keterampilan dan nilai akademik yang bisa dilihat secara langsung. Soft Skill melengkapi hard skill dan Soft skill sendiri mencakup kemampuan dan sifat manusia yang luas seperti: Kesadaran diri, dapat dipercaya, berhati nurani, mampu beradaptasi, berfikiran kritis dan sebagainya (Peggy Klaus, 2014: 10).

Sasaran belajar meliputi tiga ranah yaitu afektif, psikomotorik dan afektif. Sasaran tersebut tidak mungkin dapat dicapai dalam waktu singkat. Siswa belajar semalam suntuk untuk mengikuti tes dapat memperoleh nilai yang tinggi. Namun perolehan belajar dalam aspek kognitif demikian tidak bertahan lama. Siswa akan mudah melupakannya. Psikomotor atau keterampilan tidak dapat dicapai dalam waktu singkat. Keterampilan memerlukan waktu. Semakin banyak jam terbang seseorang, keterampilannya semakin baik dan orang tersebut menjadi lebih profesional. Keterampilan siswa yang perlu dilatih adalah menggambar, membuat tabel, grafik, menggunakan alat, merancang kegiatan, menyusun masalah, hipotesis, 
32 Widiarto, Peranan Soft Skill dan Minat Baca Terhadap Kemampuan Menulis Eksposisi Mata Pelajaran Bahasa Indonesia

melakukan eksperimen, mentabulasi data, menganalisis data, hingga ke terampil membuat laporan dan mengkomunikasikannya (ini semua merupakan tuntutan dalam KTSP).Afektif atau sikap merupakan suatu pendapat sebelum bertindak, setuju tidaknya siswa terhadap suatu fenomena, atau aturan, menjunjung tinggi kedisiplinan, tenggang rasa, mau menerima saran, bersikap objektif, menjaga kebersihan, dsb. Sikap tidak dapat dibentuk seketika. Proses pembentukan sikap memerlukan waktu, karena diperlukan adanya internalisasi dan proses psikologis seseorang. Orang yang paham dan terampil seringkali dibarengi dengan pembentukan dan perubahan sikap yang positif.

Pengamatan yang dilakukan oleh peneliti secara umum, masih ada beberapa permasalahan pembelajaran di sekolah, diantaranya: (1) Masih digunakan metode ceramah. Metode ini merupakan metode yang cenderung bersifat satu arah. Siswa hanya menerima dari guru, sehingga tidak ada interaktif antara siswa dan guru, pola ini dapat memperkecil cakupan belajar siswa. Pembelajaran yang baik seharusnya dapat memperluas interaktif siswa. Siswa lebih aktif untuk memenuhi keingintahuan (curiosty). (2) Guru lebih berperan dari ada siswa pada saat proses belajar mengajar di kelas. Proses pembelajaran yang baik, dapat mengikutsertakan keaktifan semua murid, paradigma Student Center Learning (SCL) menjadikan siswa dapat aktif mempelajari suatu konsep di kelas. (3) Kurangnya kemampuan para peserta didik untuk menulis, khususnya tulisan berjenis eksposisi. (4). Guru tidak melakukan upaya penyelesaian permasalahan kelas yang monoton membuat peserta didik menjadi malas untuk datang ke kelas. Pembelajaran dikelas perlu inovasi, sehingga siswa dapat belajar optimal,Demikian pula dengan pembelajaran menulis dikelas.Kemampuan menulis merupakan kemampuan aktif disamping berbicara.Kemampuan menulis dibutuhkan kesabaran,dan ketekunan serta minat membaca yang baik.

Menurut studi "Most Littered Nation in the World" yang dilakukan oleh Central Connecticut State University, New Britian Amerika, pada Maret 2016 lalu, Indonesia dinyatakan menduduki peringkat ke-60 dari 61 negara soal minat membaca. Indonesia tepat berada di bawah Thailand (59) dan di atas Bostwana (61). Padahal, dari segi penilaian infrastuktur untuk mendukung membaca peringkat Indonesia berada di atas negara-negara Eropa. Mengingat minat membaca hal strategis dalam pembelajaran menulis (R. Masri Sarif Putra 2008: 142), maka minat baca harus ditingkatkan. Minat baca yang masih minim, tidak terlepas dari nilainilai yang ada pada diri seorang siswa. Pembiasaan yang sudah tertanam dalam kehidupan 
sehari-hari. Pesertadidik yang mempunyai minat baca yang baik, diharapkan dapat mempunyai keterampilan menulis eksposisi dengan baik.

\section{KAJIAN TEORETIS}

\section{Kemampuan Menulis Eksposisi}

Nasucha (2009: 50) dalam bukunya mengungkapkan paragraf eksposisi bertujuan memaparkan, menjelaskan, menyampaikan informasi, mengajarkan, dan menerangkan sesuatu tanpa disertai ajakan atau desakan agar pembaca menerima atau mengikutinya. Paragraf eksposisi biasanya digunakan untuk menyajikan pengetahuan/ ilmu, definisi, pengertian, langkah-langkah suatu kegiatan, metode, cara dan proses terjadinya sesuatu.

Karangan eksposisi memiliki tujuan untuk memberikan informasi sedetail mungkin kepada para pembaca, dengan gaya penulisan yang akurat dan padat. Karangan eksposisi bersifat ilmiah disertai fakta-fakta yang ada, disesuaikan dengan topik yang dibahas Faktafakta tersebut disusun secara runut dengan menggunakan kata sambung seperti sebab akibat "dengan demikian, oleh sebab itu, oleh karena itu, jadi”, kata sambung konsesif "namun, akan tetapi, meskipun demikian" dan juga kata sambung kronologi "kemudian, lalu”.

Bahasa yang disampaikan menggunakan bahasa baku dan penyampainya bersifat mengajak namun tidak memaksakan pembacanya. Karangan eksposisi memiliki beberapa karakteristik yang harus diketahui, untuk karakteristik yang pertama yaitu karangan ini memberikan informasi yang sejelas-jelasnya kepada pembaca. Kedua pembahasan topik yang diangkat benar-benar terjadi. Ketiga bersifat mengajak namun tidak mempengaruhi atau memaksakan pembaca. Keempat menyajikan analisis terhadap fakta-fakta yang ada. Dan yang terakhir menyatakan sebuah proses kerja atau peristiwa yang terjadi. Dapat ditarik kesimpulan bahwa struktur paragraph eksposisi adalah : (1) adanya tesis, yaitu inti atau ide yang akan dipaparkan, (2) uraian mengenai ide pokok (pengembangan tesis/argument), dan (3) adanya kesimpulan yang menegaskan kembali keberadaan tesis.

\section{Minat Baca}

Mengingat minat membaca hal strategis dalam pembelajaran menulis (R. Masri Sarif Putra 2008: 142), maka minat baca harus ditingkatkan. Minat baca yang masih minim, tidak terlepas dari nilai-nilai yang ada pada diri seorang siswa. Pembiasaan yang sudah tertanam dalam kehidupan sehari-hari. Peserta didik yang mempunyai minat baca yang baik, diharapkan dapat mempunyai keterampilan menulis eksposisi dengan baik. Menurut pedapat Priyo 
34 Widiarto, Peranan Soft Skill dan Minat Baca Terhadap Kemampuan Menulis Eksposisi Mata Pelajaran Bahasa Indonesia

Sularso, Di bawah ini langkah awal untuk meningkatkan minatbaca: Pertama, bangunlah motivasi baca. Peningkatkan minat baca harus dimulai dengan motivasi diri dalam membaca. Bagi saya pribadi pandangan selintas di atas sudah cukup untuk memicu akan pentingnya membaca bagi masyarakat, sebab itu adalah sebuah keharusan bila kita ingin menguasai dunia.

Kedua, baca dengan topik yang paling disukai. Salah satu kesalahan terbesar dari seseorang yang ingin mulai membiasakan diri untuk membaca adalah image buku dan bacaan yang sebenarnya ia buat sendiri: berat dan membosankan. Padahal banyak sekali jenis buku dengan karakteristik yang beragam. Saya dulu memulainya dengan membaca cerita fiksi seperti cerpen dan novel, berlanjut ke buku-buku praktis (yang pake kata kunci: cara, langkah, tips, kiat, dll), lalu berlanjut lagi ke buku motivasi dan pengembangan diri, hingga sekarang saya sudah mulai baca buku-buku politik dan sejarah.

Ketiga menyisihkan waktu yang tepat dan nyaman untuk Membaca. Bila anggapan penting membaca itu sudah melekat, maka tidak semuanya yang baca berhasil memindahkan semua informasi yang didapat dari bacaannya itu pada memori otaknya, disebabkan momentum waktunya yang kurang tepat. Atau seringkali malas baca disebabkan waktunya kurang tepat. Beragam orang yang punya momentum baca yang tepat: ada yang suka membaca saat jam pelajaran kosong saat sekolah, atau lagi istirahat di sekolah, ada juga yang nyaman membacanya membaca saat perjalanan, beberapa saat.

\section{Soft Skill}

I Nyoman Sucipta (2009:8) menyampaikan bahwa, soft skills adalah skills yang berkaitan dengan hubungan antar manusia, seperti bagaimana melakukan conflict resolution, memahami personal dynamics, dan melakukan negosiasi. Widhiarso (2009:1) mengatakan, soft skills adalah seperangkat kemampuan yang mempengaruhi bagaimana kita berinteraksi dengan orang lain. Soft skills memuat komunikasi efektif, berpikir kreatif dan kritis, membangun tim, serta kemampuan lainnya yang terkait kapasitas kepribadian individu. Tujuan dari pelatihan soft skills adalah memberikan kesempatan kepada individu untuk mempelajari perilaku baru dan meningkatkan hubungan antar pribadi dengan orang lain.

Soft skills memiliki banyak manfaat, misalnya pengembangan karir serta etika profesional. Dari sisi organisasional, soft skills memberikan dampak terhadap kualitas manajemen secara total, efektivitas institusional dan sinergi inovasi. Esensi soft skills adalah kesempatan. Lulusan memerlukan soft skills untuk membuka dan memanfaatkan, kesempatan. 
Pentingnya soft skills tentunya dapat dilihat dari manfaat yang dirasakan oleh mahasiswa, mahasiswa yang memiliki kepercayaan diri yang tinggi tentu tidak hanya karena memiliki hard skills yang mumpuni melainkan memiliki kepribadian yang berkaitan dengan soft skills yang baik. Illah Sailah (2008) menyampaikan bila sejak awal mahasiswa dibekali dengan pengetahuan tentang soft skills yang cukup dan bahkan sudah terbiasa mempraktikkannya dalam kehidupan sehari-hari maka peluang mereka untuk menjadi orang sukses di masyarakat akan semakin besar. Perlu banyak contoh yang mahasiswa lihat di lingkungan perguruan tinggi. Contoh ini mulai dari pimpinan perguruan tinggi, dosen dan para staf penunjang yang menjadi frontliners yang berhubungan langsung dengan mahasiswa. Jika mahasiswa terbiasa diperlakukan baik dan terhormat, lambat atau cepat mereka akan menjadi pelayan yang baik di masyarakat. Inilah yang dimaksud dengan penularan yang sederhana.

Secara singkat soft skills dapat disimpulkan bahwa kemampuan yang dimiliki seseorang, yang tidak bersifat kognitif, tetapi lebih bersifat afektif yang memudahkan seseorang untuk mengerti kondisi psikologi diri sendiri, mengatur ucapan, pikiran dan sikap serta perbuatan yang sesuai dengan norma masyarakat, berkomunikasi dan berinteraksi dengan lingkungan sehingga individu tersebut dapat beradaptaasi. Meskipun soft skill yang dibutuhkan seseorang berbeda antara satu profesi dengan yang lain, pada dasarnya soft skills tidak terikat dengan budaya, karena soft skills itu bersifat universal.

\section{Elemen Soft Skills}

Soft skills memiliki beberapa komponen yang saling berkaitan antara satu dan yang lainnya. Komponen tersebut seperti rangkain organ yang membentuk sistem organ dalam tubuh yang memiliki fungsi atau tugas tertentu, saling berkaitan, dan saling mendukung antara yang satu dengan lainnya. soft skills adalah seluruh aspek dari generic skills yang juga termasuk elemen-elemen kognitif yang berhubungan dengan non-academic skills. Ditambahkan pula bahwa, berdasarkan hasil penelitian, tujuh soft skills yang diidenfikasi dan penting dikembangkan pada peserta didik di lembaga pendidikan tinggi, meliputi; keterampilan berkomunikasi (communicative skills), keterampilan berpikir dan menyelesaikan masalah (thinking skills and Problem solving skills), kekuatan kerja tim (team work force), belajar sepanjanghayat dan pengelolaan informasi (life-long learning and Information management), keterampilan wirausaha (entrepreneur skill), etika, moral dan profesionalisme (ethics, moral and professionalism), dan keterampilan kepemimpinan (leadership skills.. 
36 Widiarto, Peranan Soft Skill dan Minat Baca Terhadap Kemampuan Menulis Eksposisi Mata Pelajaran Bahasa Indonesia

\section{METODE DAN TEKNIK PENELITIAN}

Jenis data yang diambil dalam penyusunan artikel adalah data primer Pada penelitian ini memakai analisis statistik deskriptif. Pengolahan data dengan memakai SPSS 22. Analisis deskriftif merupakan analisis dengan cara mendeskripsikan atau menggambarkan data (Getut Pramesti, 49:2016). Pengambilan data dengan wawancara untuk Soft Skill dan minat baca mmakai angket, sedangkan untuk kemampuan menulis eksposisi, penulis menilai hasil karangan siswa.

Studi ini dimaksudkan untuk mendapatkan gambaran baik mengenai peranan Soft Skill, minat baca dan kemampuan menulis Eksposisi. Analisis deskriftif kuantitatif digunakan dalam mendeskripsikan data yang didapat secara jelas, dilihat dari segi peranan dan kaitannya.

Penelitian ini dilakukan di SMA Al-Ihklas Kayuringin Kota Bekasi. Subjek penelitian pada siswa kelas XI A dan XI B Tahun pelajaran 2015-2016. Jumlah siswa keseluruhan kelas sebanyak 44 siswa. Peneliti mengambil keseluruhan siswa sebagai responden. Teknik pengambilan sampel, peneliti memakai Simple Random sampling atau sampel acak sederhana Penarikan Sampel acak sederhana merupakan cara penarikan sampel yang dilakukan memilih subjek secara acak probabilitas random dan metode ini paling dekat dengan definisi probability sampling. Pengambilan sampel dari populiasi secara acak berdasarkan frekuensi probabilitas semua anggota populasi. Pada penelitian ini peneliti mengambil sampel berdasarkan kriteria seluruh siswa yang duduk di kelas XI dan XII SMA Al-Ikhlas Kayuringin Kota Bekasi. Teknik pengumpulan data yang dipakai adalah wawancara untuk Soft Skill dan minat baca memakai angket, sedangkan untuk kemampuan menulis eksposisi penulis menilai hasil karangan siswa. Wawancara dilakukan peneliti dalam situasi yang nyaman. Siswa dapat menjawab dengan baik. Wawancara memakai pertanyaan terbuka. Angket berisi tentang minat baca dijawab pada hari kedua, agar siswa benar-benar berkonsentrasi penuh. Pada hari ke tiga siswa menulis karangan eksposisi.

\section{HASIL PENELITIAN}

Para guru dapat menerapkan nilai moral pada pembelajaran di kelas. Pembelajaran moral dan Soft Skill sangat penting bagi siswa. Keberhasilan belajar yang ditunjang dengan kemampuan Soft Skill siswa akanmempunyai nilai-nilai daya juang yang tinggi, seperti kesabaran,keuletan,kemampuan berkomunikasi dan tidak mudah menyerah. Nilai-nilai tadi tentunya dapat di tanamkan sejak awal. Proses tadi dapat dilakukan secara berkesinambungan 
dan dievaluasi secara berkala. Berdasarkan hasil wawancara dan angket serta hasil karangan siswa, sebagai berikut :

Tabel 1 Deskriptif Statistik

\begin{tabular}{|c|c|c|c|c|c|c|c|}
\hline & $\mathrm{N}$ & Range & Minimum & Maximum & & Mean & Std. deviation \\
\hline & Statistic & Statistic & Statistic & Statistic & Statistic & Std. Error & Statistic \\
\hline soft_skill & 44 & 70.00 & 30.00 & 100.00 & 65.0000 & 2.79686 & 18.55225 \\
\hline minat_baca & 44 & 65.00 & 30.00 & 95.00 & 55.6818 & 2.57853 & 17.10402 \\
\hline $\begin{array}{l}\text { Kemampuan } \\
\text { Baca }\end{array}$ & 44 & 65.00 & 30.00 & 95.00 & 61.5909 & 2.34888 & 15.58072 \\
\hline $\begin{array}{l}\text { Valid N } \\
\text { (listwise) }\end{array}$ & 44 & & & & & & \\
\hline
\end{tabular}

Pada tabel 1, terlihat nilai rata-rata Soft Skill sebesar 65, Minat baca 55 dan kemampuan membaca sebesar 61. Nilai tertinggi dari soft skill sebesar 100 dan terendah 30. Nilai tertinggi minat baca 95 dan terendah 30, sedangkan kemampuan membaca untuk nilai tertinggi sebesar 95, terendah sebesar 30. Standar deviasi untuk soft skill sebesar 18.55, minat Baca sebesar 17.10 dan kemampuan membaca sebesar 15.58. Tabel 2. Bagan nilai Soft skill, minat baca dan Kemampuan menulis.

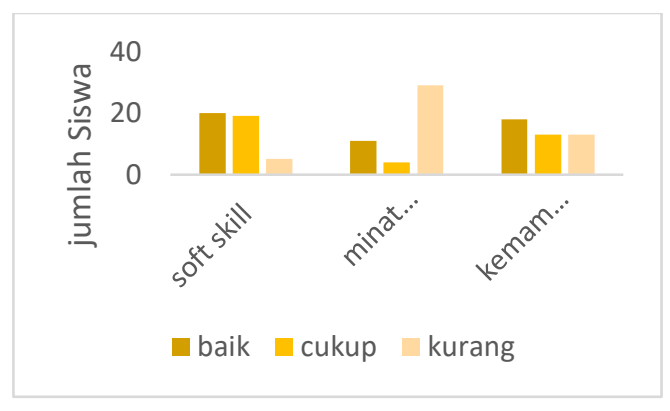

Sumber: Data yang telah diolah

Dari hasil tabel dan bagan diatas terdapat 44 siswa yang mempunyai soft skill baik (45.5 $\%), 19$ siswa katagori cukup (43.1\%) dan siswa katagori kurang sebanyak 5 siswa (11.4\%). Siswa yang mempunyai minat baca katagori baik sebanyak 11 siswa (25\%),4 siswa katagori cukup $(9.1 \%)$ dan 29 siswa kategori kurang (65,9\%). Pada kemampuan menulis siswa yang mempunyai kemampuan menulis katagori baik sebanyak 18 siswa (41\%), cukup sebanyak 13 siswa $(29.5 \%)$ dan kurang sebanyak 13 siswa (29,5\%). 
38 Widiarto, Peranan Soft Skill dan Minat Baca Terhadap Kemampuan Menulis Eksposisi Mata Pelajaran Bahasa Indonesia

\section{SIMPULAN DAN SARAN}

Pembelajaran dikelas mempunyai makna yang penting bagi siswa. Pembelajaran yang diikuti dengan Soft skill akan menjadi bekal untuk menghadapi kehidupan dimasa yang akan datang. Soft skill berperan dalam kemampuan menulis siswa, demikian pula dengan minat baca. Minat baca dapat di tingkatkan seiring diberikannya pembelajaran tentang Soft Skill di sekolah. Soft Skill mempunyai peran yang penting, bagi anak .Para guru hendaknya dapat berperan lebih aktif dalam penanaman nilai-nilai moral .Karakter yang baik dapat diberikan sejak anak belajar pada pendidikan usia dini.Pembelajaran Soft skill memerlukan waktu dan usaha yang panjang.Untuk itu para orang tua sebaiknya lebih berperan aktif.

Para orang tua di rumah dapat mengajarkan siswa Soft Skill lebih intensif. Melihat hasil data diatas menunjukan bahwa siswa yang mempunyai soft skill yang baik, sebanyak 19 siswa, sedangkan siswa yang mempunyai kemampuan menulis katagori baik sebanyak 18 siswa.

Guru dan para orang tua murid disarankan dapat membantu program pendidikan soft skill dan sebaiknya dapat saling bekerjasama antara orang tua murid dan guru. Keterampilan Soft Skill sangat diperlukan dalam menghadapi persaingan global yang sudah diberlakukan di Indonesia.Pendidikan Soft Skill tidak kalah penting dengan Hard Skill atau prestasi akademik,karena dengan Soft Skill yang baik akan sangat membantu dalam karir dan kecakapan kerja dikemudian hari.

\section{DAFTAR PUSTAKA}

Aman Saleh Mohd, (2016) Memaksimalkan Potensi Soft skill X Factor Dalam Diri Jakarta Chen Victoria Febe, (2013), Soft Skill for Success: Pandai Membawa Diri di Dunia Kerja, BIP. Jakarta.

Klauss Peggy, (2014) Jangan Anggap Sepele Soft Skill, Jakarta. Libri

Putra Sareb Masri R (2008), Menumbuhkan minat baca. Jakarta PT Indeks

Pramesti Getut, (2016) Panduan Lengkap SPSS 22. Jakarta. Elekmedia Komputindo

Sutrisno dan Adjib Karjanto, (2014) Peningkatan Soft Skill dan Prestasi belajar mahasiswa pada mata kuliah Metodologi Penelitian melalui Pembelajaran Model Learning Community.Jurnal Vol.37 No.1, 2538

I Nyoman Sucipta. (2009). Holistik Soft Skills. Denpasar: Udayana University Press

Illah Sailah (2008). Pengembangan Soft Skills Di Perguruan Tinggi. Jakarta: Direktorat Jenderal Pendidikan Tinggi

Zaman Saeful (2013), Buku Pintar Soft Skill,Jakarta PT Dwitama Asrimedia http:edukasi.kompas.com/read/2016/08/29/07175131/minat.baca.indonesia.ada. di.urutan.ke-60. dunia diakses pada tanggal 26 Oktober 2016 